\title{
The benign c.344G > A: p.(Arg115His) variant in the $L D L R$ gene interpreted from a pedigree-based genetic analysis of familial hypercholesterolemia
}

\author{
Mika Hori ${ }^{1 *}$, Atsushi Takahashi ${ }^{2}$, Cheol Son ${ }^{3}$, Masatsune Ogura ${ }^{1}$ and Mariko Harada-Shiba ${ }^{1 *}$
}

\begin{abstract}
Background: We previously identified the c.344G > A: p.(Arg115His) variant in the low-density lipoprotein receptor $(L D L R)$ gene, which was interpreted as "conflicting interpretations of pathogenicity" in ClinVar, based on a genetic analysis of patients with familial hypercholesterolemia (FH). However, whether this variant affects the pathophysiology of FH remains unclear. Therefore, our aim was to annotate the c.344G > A: p.(Arg115His) variant in the $L D L R$ gene in FH. We present 2 families harboring the c.344G > A: p.(Arg115His) variant in the $L D L R$ gene.

Methods: Genetic analyses were performed for the coding regions and the exon-intron boundary sequence of the $L D L R$ and proprotein convertase subtilisin/kexin type 9 (PCSK9) genes in $2 \mathrm{FH}$ families. Next, the family without pathogenic variants in the LDLR and PCSK9 genes was screened by whole-exome sequencing. Detailed clinical and biochemical data were gathered from family members.

Results: In one family, the index case had biallelic c.1567G > A: p.(Val523Met) and c.344G > A: p.(Arg115His) variants in the $L D L R$ gene, while the sibling had only the c.1567G > A: p.(Val523Met) variant in the $L D L R$ gene. There was no difference in the $\mathrm{FH}$ phenotype between the siblings. In another family, the index case and the sibling had no pathogenic variants in the LDLR, PCSK9, and apolipoprotein B (APOB) genes, but the sibling's wife with nonFH had the c.344G > A: p.(Arg115His) variant in the LDLR gene. The sibling and his wife had 4 children, including an unaffected child and an affected child who had the c.344G > A: p.(Arg115His) variant in the LDLR gene. In addition, the allele frequency of the c.344G > A: p.(Arg115His) variant (0.0023-0.0043) in Japanese and East Asian populations is relatively high compared with that of the other $L D L R$ pathogenic variants $(0.0001-0.0008)$.
\end{abstract}

Conclusions: The c.344G > A: p.(Arg115His) variant in the $L D L R$ gene is interpreted as benign in individuals with FH. Keywords: LDL receptor, Familial hypercholesterolemia, Variant, Benign, Annotation

\footnotetext{
*Correspondence: mihori@ncvc.go.jp; mshiba@ncvc.go.jp

'Department of Molecular Innovation in Lipidology, National Cerebral and

Cardiovascular Center Research Institute, 6-1 Kishibe-Shimmachi, Suita, Osaka 564-8565, Japan

Full list of author information is available at the end of the article
}

(C) The Author(s). 2020 Open Access This article is licensed under a Creative Commons Attribution 4.0 International License, which permits use, sharing, adaptation, distribution and reproduction in any medium or format, as long as you give appropriate credit to the original author(s) and the source, provide a link to the Creative Commons licence, and indicate if changes were made. The images or other third party material in this article are included in the article's Creative Commons licence, unless indicated otherwise in a credit line to the material. If material is not included in the article's Creative Commons licence and your intended use is not permitted by statutory regulation or exceeds the permitted use, you will need to obtain permission directly from the copyright holder. To view a copy of this licence, visit http://creativecommons.org/licenses/by/4.0/ The Creative Commons Public Domain Dedication waiver (http://creativecommons.org/publicdomain/zero/1.0/) applies to the data made available in this article, unless otherwise stated in a credit line to the data. 


\section{Background}

Familial hypercholesterolemia $(\mathrm{FH})$ is a disease that leads to a high risk of coronary artery disease (CAD) because FH patients are exposed to high serum LDLcholesterol (LDL-C) levels from birth. The prevalence of FH is 1 per $200-500$ individuals in the general population [1]. FH is caused by mutations in the low-density lipoprotein receptor $(L D L R)$ and in the related genes apolipoprotein $\mathrm{B}(A P O B)$ and proprotein convertase subtilisin/kexin type 9 (PCSK9). More than 4970 variants in the $L D L R$ gene, 580 variants in the $A P O B$ gene, and 350 variants in the PCSK9 gene are shown in ClinVar [2]. In Japan, pathogenic variants in the $A P O B$ gene have not been reported [3]. Whether some variants of the $L D L R$ and PCSK9 genes affect the pathophysiology of FH remains unclear.

In our $\mathrm{FH}$ cohort, patients were found to harbor the c.344G > A: p.(Arg115His) variant in the $L D L R$ gene, which was interpreted as "conflicting interpretations of pathogenicity" in ClinVar. However, whether this variant affects the pathophysiology of $\mathrm{FH}$ remains to be elucidated. Herein, we present 2 families harboring the c.344G > A: p.(Arg115His) variant in the LDLR gene, including an index case with biallelic $L D L R$ variants that comprised the c.344G > A: p.(Arg115His) and a pathogenic variant (Family 1) and nonFH patients with the c.344G > A: p.(Arg115His) variant (Family 2).

\section{Methods}

The protocol of this study was approved by the Ethics Review Committee of the National Cerebral and Cardiovascular Center (M17-56 or M24-80). Each patient provided written informed consent to participate in the study.

\section{DNA analysis}

Genomic DNA was extracted from whole blood from the sibling of Family 1 and the index case of Family 2 using an automated DNA extraction machine (QIAsymphony; QIAGEN, Valencia, CA) and from the other members of Family 2 using the Genome Extraction Kit (GENOMIX; Biologica, Nagoya, JAPAN) by SRL Inc. (Tokyo, JAPAN). The coding regions and exon-intron boundary sequences of the LDLR and PCSK9 genes were examined by Sanger sequencing as described previously [4]. For the index case of Family 2, multiplex ligationdependent probe amplification (MLPA) was performed to detect large rearrangements of the $L D L R$ gene using the P062B LDLR MLPA Kit (MRC Holland, Amsterdam, the Netherlands). Next, whole-exome sequencing was performed for Family 2. Exome libraries were prepared using the SureSelect Human All Exon V7 Kit (Agilent Technologies, Santa Clara, CA). Sequencing was performed by NovaSeq 6000 (Illumina, San Diego, CA) with $150 \mathrm{bp}$ paired-end reads at RIKEN GENESIS CO., LTD.
Sequence reads were aligned to the human reference genome (hg19) using BWA-MEM. Single nucleotide variants and small indels were called with HaplotypeCaller of the Genome Analysis Tool Kit. The presence/absence of the c.344G > A:p.(Arg115His) variant in the $L D L R$ gene was confirmed by Sanger sequencing.

\section{Clinical and laboratory data}

Serum total cholesterol (TC), triglycerides (TG), and high-density lipoprotein-cholesterol (HDL-C) levels were measured using enzymatic methods. LDL-C levels were calculated by the Friedewald formula or were measured using enzymatic methods. Achilles tendon thickness (ATT) was measured by X-ray. CAD was evaluated by the presence of myocardial infarction, angina pectoris, or coronary arteries with $\geq 75 \%$ stenosis by coronary angiography or electrocardiogram.

\section{Results \\ Case presentation \\ Family 1}

The index case was a 19-year-old woman who had biallelic $L D L R$ c.1567G > A: p.(Val523Met) and c.344G > A: p.(Arg115His) variants (Fig. 1, Table 1). She was referred to our lipid clinic with her brother at the age of 19 years for dyslipidemia, and her untreated LDL-C level was $208 \mathrm{mg} / \mathrm{dL}$. She did not have ATT. Her medications included $2.5 \mathrm{mg}$ of rosuvastatin, and her LDL-C level was $100 \mathrm{mg} / \mathrm{dL}$ on this medication regimen. Her sibling (II1) was a 21 -year-old male who had the $L D L R$ c.1567G > A: p.(Val523Met) variant. His untreated LDL-C level was $204 \mathrm{mg} / \mathrm{dL}$ at 21 years old. His ATT values were 6.7 and $9.1 \mathrm{~mm}$. His medication included $2.5 \mathrm{mg}$ of rosuvastatin, and his LDL-C level was $99 \mathrm{mg} / \mathrm{dL}$ under this medication regimen. Their father was diagnosed with $\mathrm{FH}$, but his lipid profile was unknown.

\section{Family 2}

The index case was a 52-year-old man who had no pathogenic variants in the $L D L R$ and PCSK9 genes (Fig. 1). He was referred to the lipid clinic at the age of 52 years for dyslipidemia (II-1). His untreated LDL-C level was 237 $\mathrm{mg} / \mathrm{dL}$, and his ATT values were $7.1 \mathrm{~mm}$ and $9.2 \mathrm{~mm}$. He was diagnosed with hypertension at the age of 45 years. His medication regimen included $5 \mathrm{mg}$ of rosuvastatin and $10 \mathrm{mg}$ of ezetimibe, and his LDL-C level was $111 \mathrm{mg} /$ $\mathrm{dL}$ under this regimen. The lipid profiles of his parents were unknown. His father died of liver cancer at 65 years old, and his mother died at 64 years old due to unknown causes. The sibling (II-2) of the index case was a 49-yearold man who was diagnosed with FH. His medication regimen included $2 \mathrm{mg}$ of rosuvastatin, $10 \mathrm{mg}$ of ezetimibe, and $2 \mathrm{~g}$ of omega- 3 fatty acid ethyl, and his LDL-C level was $106 \mathrm{mg} / \mathrm{dL}$ under this regimen. The index case and 


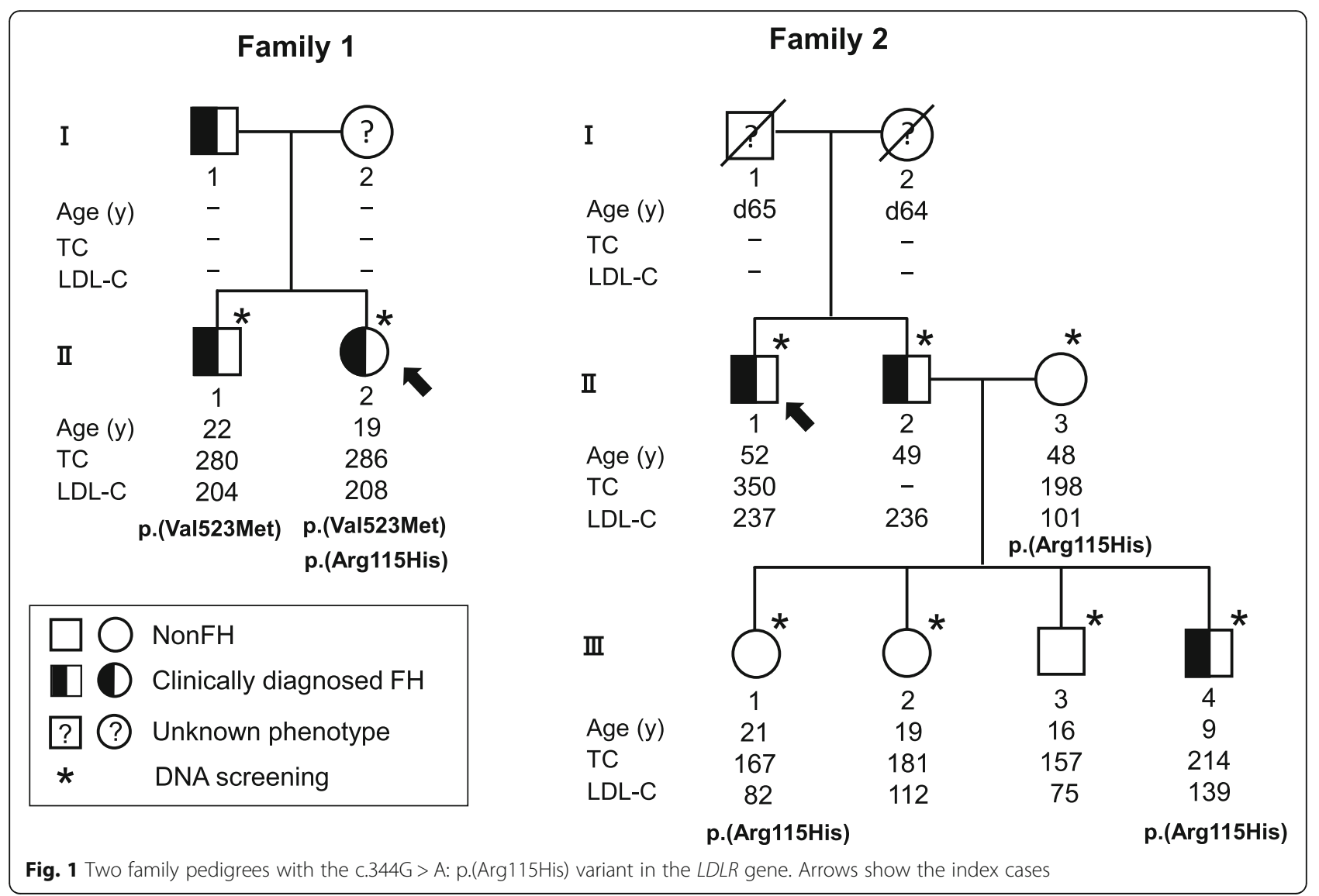

Table 1 Clinical and genetic characteristcs of the family with the c.344G > A: p.(Arg115His) variant in the LDLR gene

\begin{tabular}{|c|c|c|c|c|c|c|c|c|c|}
\hline Family & 1 & & 2 & & & & & & \\
\hline Case & $\|-1$ & $\| 1-2$ & $\|-1$ & II-2 & $11-3$ & $|I| \mid-1$ & $|I|-2$ & $|I|-3$ & || $\mid-4$ \\
\hline Clinical diagnosis & $\mathrm{FH}$ & $\mathrm{FH}$ & $\mathrm{FH}$ & $\mathrm{FH}$ & nonFH & nonFH & nonFH & nonFH & $\mathrm{FH}$ \\
\hline Age $(y)$ & 22 & 19 & 52 & 49 & 48 & 21 & 19 & 16 & 9 \\
\hline Sex & M & $\mathrm{F}$ & M & M & $\mathrm{F}$ & $\mathrm{F}$ & $\mathrm{F}$ & M & M \\
\hline $\mathrm{TC}(\mathrm{mg} / \mathrm{dL})$ & 280 & 286 & 350 & - & 198 & 167 & 181 & 157 & 214 \\
\hline $\mathrm{TG}(\mathrm{mg} / \mathrm{dL})$ & 42 & 58 & 239 & 137 & 262 & 77 & 53 & 71 & 153 \\
\hline $\mathrm{HDL}-\mathrm{C}(\mathrm{mg} / \mathrm{dL})$ & 68 & 66 & - & 49 & 45 & 70 & 58 & 68 & 44 \\
\hline $\mathrm{LDL}-\mathrm{C}(\mathrm{mg} / \mathrm{dL})$ & 204 & 208 & 237 & 236 & 101 & 82 & 112 & 75 & 139 \\
\hline $\begin{array}{l}\text { Achilless tendon } \\
\text { thickness }\end{array}$ & Yes & No & Yes & Yes & No & No & No & No & No \\
\hline Xanthoma & No & No & No & No & No & No & No & No & No \\
\hline Corneal Acrus & No & No & Yes & Yes & No & No & No & No & No \\
\hline CAD & No & No & No & No & No & No & No & No & No \\
\hline $\begin{array}{l}\angle D L R \text { pathogenic } \\
\text { variant }\end{array}$ & $\begin{array}{l}\text { c.1567G > A: } \\
\text { p.(Val523Met) }\end{array}$ & $\begin{array}{l}\text { c.1567G > A: } \\
\text { p.(Val523Met) }\end{array}$ & None & None & None & None & None & None & None \\
\hline$L D L R$ variant & None & $\begin{array}{l}\text { c.344G > A: } \\
\text { p.(Arg115His) }\end{array}$ & None & None & $\begin{array}{l}\text { c.344G > A: } \\
\text { p.(Arg115His) }\end{array}$ & $\begin{array}{l}\text { c.344G > A: } \\
\text { p.(Arg115His) }\end{array}$ & None & None & $\begin{array}{l}\text { c.344G > A: } \\
\text { p.(Arg115His) }\end{array}$ \\
\hline $\begin{array}{l}\text { PCSK9 pathogenic } \\
\text { variants }\end{array}$ & None & None & None & None & None & None & None & None & None \\
\hline
\end{tabular}


the sibling's family were screened by whole-exome sequencing. We examined the coding regions and exonintron boundary sequences in the LDLR, PCSK9, and $A P O B$ genes. The index case and the sibling had no pathogenic variants in the $L D L R, P C S K 9$, and $A P O B$ genes, but the wife of the sibling (II-3) with nonFH had the c.344G > A: p.(Arg115His) variant in the $L D L R$ gene. They had no loss-of-function mutations in the PCSK9 and $A P O B$ genes. The sibling and the wife had 4 children, of whom 3 siblings (III-1, III-2, and III-3) were diagnosed with nonFH and 1 sibling (III-4) was diagnosed with FH. The eldest daughter (III-1) and the youngest son (III-4) were heterozygous for the c.344G > A: p.(Arg115His) variant in the $L D L R$ gene. The presence/absence of the c.344G > A: p.(Arg115His) variant in the $L D L R$ gene was confirmed by Sanger sequencing.

Allele frequency of the c.344G > A: p.(Arg115His) variant in the $L D L R$ gene in Japanese and East Asian populations.

The allele frequency of the c.344G > A: p.(Arg115His) variant in the $L D L R$ gene in Japanese and East Asian populations was $0.0029,0.0043$, and 0.0023 according to the Japanese Human Genetic Variation Database $(n=1201$; HGVD: http://www.genome.med.kyoto-u.ac.jp/SnpDB) [5], the Tohoku Medical Megabank Organization database $(n=3381$; tommo_3.5KJPN) [6], and ExAC $(n=66,000$, [7]), respectively. The allele frequency of the c.344G > A: p.(Arg115His) variant in the $L D L R$ gene was relatively high compared with that of the other $L D L R$ pathogenic variants (0.0001-0.0008) detected in these databases.

\section{Discussion}

We present 2 families harboring the c.344G $>$ A: p.(Arg115His) variant in the $L D L R$ gene. In the first family (Family 1), we identified an index case of biallelic $L D L R$ variants that included c.1567G > A: p.(Val523Met) and c.344G > A: p.(Arg115His), and in the second family (Family 2), we identified that the wife of the index case's sibling with $\mathrm{FH}$, who was normolipidemic, had the $L D L R$ c.344G > A: p.(Arg115His) variant. In Family 1, the index case had biallelic $L D L R$ variants that included c.1567G > A: p.(Val523Met) and c.344G > A: p.(Arg115His), while the sibling had only the heterozygous c. $1567 \mathrm{G}>\mathrm{A}$ : p.(Val523Met) variant in the $L D L R$ gene. The c.1567G > A: p.(Val523Met) variant is defined as pathogenic/likely pathogenic in ClinVar. FH patients harboring biallelic $L D L R$ pathogenic variants generally show a much more severe phenotype than those harboring heterozygous $L D L R$ pathogenic variants. However, the phenotype of the index case in Family 1 was identical to that of heterozygous FH. In Family 2, the index case's sibling with FH had 4 children, namely, 1 affected and 3 unaffected siblings. His wife with nonFH had the c.344G > A: p.(Arg115His) variant in the $L D L R$ gene. A heterozygous
c.344G > A: p.(Arg115His) variant in the $L D L R$ gene was detected in 1 unaffected sibling and 1 affected sibling. The $\mathrm{FH}$ phenotype of the youngest son is suggested to be derived from his father harboring unknown pathogenic variants.

The c.344G > A: p.(Arg115His) variant in the $L D L R$ gene has been reported in several individuals of Asian ethnicity $[3,8]$. The allele frequency of the c.344G $>$ A: p.(Arg115His) (0.029/0.0043) variant in the $L D L R$ gene among the Japanese population was similar to that expected based on the prevalence of heterozygous $\mathrm{FH}$ among the Japanese population (0.002-0.005). The allele frequency of the c.344G > A: p. $(\operatorname{Arg} 115 \mathrm{His})$ variant in the $L D L R$ gene is relatively high compared with that of other $L D L R$ pathogenic variants $(0.0001-0.0008)$ in Japanese databases. The $L D L R$ gene is located on chromosome 19p13.1-13.3 and contains 18 exons, encoding a mature protein of 839 amino acids with a 21 amino acid signal peptide. The c.344G > A: p.(Arg115His) variant is located in the cysteine-rich, 40 amino acid repeat region of the binding domain of the LDLR, but the 115th Arg is not conserved among this region [9]. In addition, the Arg ( $\mathrm{pI}=$ 10.76) to His ( $\mathrm{pI}=7.59)$ substitution does not change the positive charge of this sequence. For the c.344G > A: p.(Arg115His) variant, only one study exists; functional assay results revealed that receptor activities were $64 \%$ of normal in COS7 cells transfected with LDLR cDNA containing the c.344G > A: p.(Arg115His) variant [10]. However, the genotype-phenotype correlation of the c.344G > A:p.(Arg115His) in the $L D L R$ gene in pedigrees has not been demonstrated. Thus, based on 2 pedigree-based genetic analyses, the c.344G > A: p.(Arg115His) variant in the $L D L R$ gene was classified as benign according to the guidelines issued by the American College of Medical Genetics and Genomics and the Association for Molecular Pathology. Thus, examining the genotype-phenotype correlation in a pedigree is important for providing a genetic diagnosis with high accuracy.

In our cohort, we showed that unrelated patients harboring no pathogenic variants in the LDLR and PCSK9 genes comprised approximately $40 \%$ of $\mathrm{FH}$ patients [4]. FH may be partly explained by the accumulation of common SNPs [11]. A number of factors, including somatic genetic changes, environmental factors, and other genetic factors, might contribute to the pathogenesis and phenotypic variations observed in FH. We are currently searching for new candidate $\mathrm{FH}$ genes that may be responsible for FH in Family 2. Finally, in vitro functional analyses are needed to quantify the actual effect of the c.344G > A: p.(Arg115His) variant in the $L D L R$ gene.

\section{Conclusions}

The c.344G > A: p.(Arg115His) variant in the $L D L R$ gene was not shared by the sibling with $\mathrm{FH}$ in Family 1, and patients with nonFH also had the variant in Family 2. In 
conclusion, the c.344G > A: p.(Arg115His) variant in the $L D L R$ gene is interpreted as benign based on pedigreebased genetic analysis.

\section{Abbreviations}

APOB: Apolipoprotein B; ATT: Achilles tendon thickness; CAD: Coronary artery disease; FH: Familial hypercholesterolemia; HDL: High-density lipoprotein; HDL-C: HDL-cholesterol; LDL: Low-density lipoprotein; LDL-C: LDL-cholesterol; LDLR: LDL receptor; MLPA: Multiplex ligation-dependent probe amplification; PCSK9: Proprotein convertase subtilisin/kexin type 9: TC: Total cholesterol; TG: Triglycerides

\section{Acknowledgments}

We thank Dr. Yoshihiro Miyamoto, Mr. Suguru Yamamoto, Mr. Naotaka Ohta, Mr. Hiroaki Masuda, and Ms. Rieko Isoda for DNA analysis and Ms. Rie Oishi for clerical support.

\section{Authors' contributions}

M.H. collected the clinical data, and M.H., M.O. and M.H-S. contributed to the interpretation of the data. A.T. performed bioinformatic analysis in wholeexome sequencing. M.H. and C. S performed the genetic analysis by Sanger sequencing. M.H. drafted the manuscript and contributed to the conception and design of the study. M.H-S. contributed to the study's supervision. All authors gave final approval of the submitted version.

\section{Funding}

This work was partly supported by grants from the Ministry of Health, Labor and Welfare of Japan for Clinical Research on Intractable Diseases (H26-nanjiippan-056, H30-nanji-ippan-003), JSPS KAKENHI Grant Number JP17K08681, the Japan Agency for Medical Research and Development

(16ek0210075h0001), the Intramural Research Fund (28-2-2; 29-6-11) for Cardiovascular Diseases of the National Cerebral and Cardiovascular Center, the Japan Heart Foundation \& Astellas Grant for Research on Atherosclerosis Update, the Takeda Science Foundation, the Kanae Foundation for the Promotion of Medical Science, Novartis Research Grants, and The Japanese Circulation Society.

\section{Availability of data and materials}

The data are not available because some data are being used by another study.

\section{Ethics approval and consent to participate}

The protocol of this study was approved by the Ethics Review Committee of the National Cerebral and Cardiovascular Center (M17-56 or M24-80). Each patient provided written informed consent to participate in the study.

\section{Consent for publication}

All the participants provided written informed consent for the publication of the results of this study.

\section{Competing interests}

The authors declare that they have no competing interests.

\section{Author details}

'Department of Molecular Innovation in Lipidology, National Cerebral and Cardiovascular Center Research Institute, 6-1 Kishibe-Shimmachi, Suita, Osaka 564-8565, Japan. ${ }^{2}$ Department of Genomic Medicine, National Cerebral and Cardiovascular Center Research Institute, 6-1 Kishibe-Shimmachi, Suita, Osaka 564-8565, Japan. ${ }^{3}$ Laboratory of Clinical Genetics, National Cerebral and Cardiovascular Center, 6-1 Kishibe-Shimmachi, Suita, Osaka 564-8565, Japan.

Received: 18 November 2019 Accepted: 31 March 2020

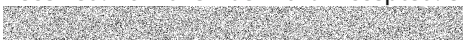

\section{References}

1. Mabuchi H, Nohara A, Noguchi T, Kobayashi J, Kawashiri MA, Tada H, et al. Molecular genetic epidemiology of homozygous familial hypercholesterolemia in the Hokuriku district of Japan. Atherosclerosis. 2011; 214:404-7.
2. Iacocca MA, Chora JR, Carrie A, Freiberger T, Leigh SE, Defesche JC, et al ClinVar database of global familial hypercholesterolemia-associated DNA variants. Hum Mutat. 2018;39:1631-40.

3. Yu W, Nohara A, Higashikata T, Lu H, Inazu A, Mabuchi H. Molecular genetic analysis of familial hypercholesterolemia: spectrum and regional difference of $L D L$ receptor gene mutations in Japanese population. Atherosclerosis. 2002:165:335-42.

4. Hori M, Ohta N, Takahashi A, Masuda H, Isoda R, Yamamoto S, et al. Impact of LDLR and PCSK9 pathogenic variants in Japanese heterozygous familial hypercholesterolemia patients. Atherosclerosis. 2019;289:101-8.

5. Higasa K, Miyake N, Yoshimura J, Okamura K, Niihori T, Saitsu H, et al. Human genetic variation database, a reference database of genetic variations in the Japanese population. J Hum Genet. 2016;61:547-53.

6. Nagasaki M, Yasuda J, Katsuoka F, Nariai N, Kojima K, Kawai Y, et al. Rare variant discovery by deep whole-genome sequencing of 1,070 Japanese individuals. Nat Commun. 2015;6:8018.

7. Lek M, Karczewski KJ, Minikel EV, Samocha KE, Banks E, Fennell T, et al. Analysis of protein-coding genetic variation in 60,706 humans. Nature. 2016 536:285-91.

8. Kim JH, Choi HK, Lee H, Park HY, Kim JH, Kim JW, et al. Novel and recurrent mutations of the LDL receptor gene in Korean patients with familial hypercholesterolemia. Mol Cells. 2004;18:63-70.

9. Sudhof TC, Goldstein $J$, Brown MS, Russell DW. The LDL receptor gene: a mosaic of exons shared with different proteins. Science. 1985:228:815-22.

10. Chang JH, Pan JP, Tai DY, Huang AC, Li PH, Ho HL, et al. Identification and characterization of LDL receptor gene mutations in hyperlipidemic Chinese. J Lipid Res. 2003;44:1850-8.

11. Talmud PJ, Shah S, Whittall R, Futema M, Howard P, Cooper JA, et al. Use of low-density lipoprotein cholesterol gene score to distinguish patients with polygenic and monogenic familial hypercholesterolaemia: a case-control study. Lancet. 2013;381:1293-301.

\section{Publisher's Note}

Springer Nature remains neutral with regard to jurisdictional claims in published maps and institutional affiliations.
Ready to submit your research? Choose BMC and benefit from:

- fast, convenient online submission

- thorough peer review by experienced researchers in your field

- rapid publication on acceptance

- support for research data, including large and complex data types

- gold Open Access which fosters wider collaboration and increased citations

- maximum visibility for your research: over $100 \mathrm{M}$ website views per year

At $\mathrm{BMC}$, research is always in progress.

Learn more biomedcentral.com/submissions 